\title{
Kebijakan Penyelamatan 1000 Hari Pertama Kehidupan (1000 HPK) dan Penurunan Stunting di Kota Semarang
}

\author{
Agus Samsudrajat $S^{*}$, Sutopo Patria Jati**, \\ *Prodi Kesmas FIKES Universitas Muhammadiyah Pontianak, \\ **Fakultas Kesehatan Masyarakat, Universitas Diponegoro, Semarang \\ Jl.Prof.H.Soedarto, S.H.Tembalang, Tembalang, Kota Semarang, Jawa Tengah 50275 \\ Email: samsoe.skm@gmail.com
}

\section{ABSTRACT:}

Stunting is considered a chronic problem if the prevalence is $20 \%$ or more. Nutrition Status Monitoring Results (PSG) 2017 Semarang City stunting 21\%, while 2016 only 16.5\%. Presidential Regulation 42/2013 concerning the national movement to accelerate nutrition improvement leads to saving the first thousand days of life (1000 HPK) \& reducing stunting. While the City of Semarang chose to issue a Regional Regulation on the Safety of Mother and Child (MCH). This study aims to analyze the 1,000 HPK rescue policy and stunting reduction in the city of Semarang.

This study was an observational study with a descriptive qualitative design through in-depth interviews and observations. The main informants were seven informants from municipal government agencies. Triangulation informants consisted of five informants from the city and sub-district level. The research analysis uses a policy triangle analysis namely content, context and process.
The results of research by content of $\mathrm{MCH}$ regulations have not yet focused on the efforts of 1000 HPK and stunting. The content of the MCH Regulation is more focused and dominant in regulating specific intervention efforts related to health services. While the non-health sector for sensitive interventions has not been regulated much and entered into Perda. Efforts to save $1000 \mathrm{HPK}$ and stunting were found to have been discussed in a Regional Action Plan (RAD) study, but they were not completed. In the political, economic and socio-cultural context, $\mathrm{MCH}$ regulations are not focused, not directly related, and do not involve all interventions to save 1,000 HPK and stunting. In the process, both formulation and evaluation of the $M C H$ regulations have not involved all sectors, including and evaluating sensitive and specific nonhealth interventions that lead to $1000 \mathrm{HPK}$ and stunting. The $1000 \mathrm{HPK}$ policy and stunting reduction have been directed to the RAD study, but there has been no cross-sectoral coordination and the study stopped at the Semarang City Regional Development Planning Agency. 
Keywords: policy, 1000 HPK, stunting

\section{PENDAHULUAN}

Masalah gizi stunting dianggap sebagai kategori kronis jika prevalensinya $20 \%$ atau lebih. ${ }^{1}$ Rencana Pembangunan Jangka Menengah Nasional (RPJMN) 2015-2019 menargetkan penurunan angka stunting 28\% untuk anak dibawah dua tahun (baduta) pada tahun 2019. ${ }^{2}$ Kerangka Intervensi masalah gizi stunting yang dilakukan oleh pemerintah Indonesia terbagi menjadi dua dan keduanya harus berjalan bersama, yaitu Intervensi gizi spesifik (langsung) dan intervensi gizi sensitif (tidak langsung). ${ }^{3,4}$ Pemantauan Status Gizi (PSG) 2017 mencatat stunting di Kota Semarang masuk menjadi salah satu wilayah dengan kategori kronis dengan kasus 21\%. ${ }^{5}$ Meningkat dari tahun sebelumnya 2016 yang hanya $16,5 \%{ }^{6}$

Intervensi spesifik hanya mampu memberikan kontribusi $30 \%$ untuk masalah gizi seperti stunting. Mengingat kompleknya masalah stunting di masyarakat, penuntasanya yang $70 \%$ memerlukan keterlibatan lintas sektor pembangunan lain diluar sektor kesehatan atau yang disebut dengan intervensi sensitif. $^{2-4}$ Tetapi banyaknya sektor (stakeholders) yang terlibat menyebabkan program tidak berjalan dengan baik atau kurang sinkron. ${ }^{7}$

Menurut Buse et all, kebijakan merupakan salah satu komponen penting yang sangat mempengaruhi ekonomi, bahkan jika terkait dengan kesehatan dampaknya bisa sampai kepada masalah hidup dan mati. Kebijakan yang tidak baik menjadi sebuah pintu awal tidak tercapainya tujuan, terjadinya konflik dan tidak harmonisnya hubungan pusat dan daerah. Kebijakan juga menjadi alat bukti sejauh mana keseriusan pemerintah dalam proses melayani dan menyediakan arah dan rambu-rambu sesuai keadaan dan kemampuan dalam mencapai tujuan pembangunan. ${ }^{8}$

Peraturan Presiden (Perpres) 42/2013 tentang gerakan nasional percepatan perbaikan gizi mengarahkan pada penyelamatan seribu hari pertama kehidupan (1000 HPK) dan penurunan stunting. ${ }^{9}$ Pada tahun 2015 Kota Semarang membuat Peraturan Daerah (Perda) tentang Keselamatan Ibu dan Anak (KIA). ${ }^{10}$

\section{METODE PENELITIAN}

Penelitian ini adalah penelitian observasional dengan rancangan kualitatif secara deskriptif melalui wawancara mendalam dan telaah dokumen. Subjek penelitian diambil secara purposive sampling informasi yang sesuai dengan tujuan penelitian. Penelitian dilakukan di sektor Pemerintahan Kota Semarang. Informan utama berjumlah tujuh informan yang masing-masing terdiri dari instansi pemerintah tingkat kota. Informan triangulasi ada lima yang terdiri satu instansi tingkat kota dan empat instansi tingkat kecamatan. Analisis penelitian menggunakan analisis segitiga kebijakan yaitu content, context dan process. ${ }^{11-14}$

\section{HASIL DAN PEMBAHASAN \\ Hasil}

\section{Karakteristik Informan}

Informan utama terdiri dari 57\% laki-laki dan $43 \%$ informan perempuan. $57 \%$ Informan utama memiliki pendidikan strata dua dan $43 \%$ informan strata satu. Jabatan informan 29\% Kepala Dinas dan 71\% Kepala Bidang atau Kepala Seksi. Masa kerja informan 57\% (2-4 tahun) 43\% (5-10 tahun) di bidang dan instansi yang sama. $86 \%$ informan utama dari sektor 
pemerintah non kesehatan dan 14\% dari sektor pemerintah kesehatan. Informan triangulasi terdiri $60 \%$ sektor pemerintah non kesehatan dan $40 \%$ sektor pemerintah kesehatan dengan $60 \%$ masa kerja 20-30 tahun dan 40\% 3-5 tahun.

\section{Content}

Didapatkan hasil bahwa hanya ada dua dari tujuh informan utama yang pernah mendapatkan informasi tentang 1000 HPK dan stunting. Demikian juga dengan informasi Perda KIA kota Semarang hanya dua dari tujuh informan yang mengaku mengetahui dan ikut terlibat dalam melakukan pembahasan tentang content kebijakan. Tetapi dari dua informan yang mengetahui tersebut hanya satu informan yang memahami dan mengetahui adanya kebijakan nasional perpres 42/2013 tentang gerakan nasional percepatan perbaikan gizi yang fokus pada upaya 1000 HPK dan penurunan stunting.

'...Iya pernah ada sosialisasi terkait stunting, kami juga terlibat saat perumusan perda KIA, kalau kebijakan nasional perpres saya kurang tahu..." (IU.5)

“...Iya wong kami yang jadi tim inti perda itu, ada DP3A dan KB juga., Kalau Perda KIA untuk AKI, kalau 1000 HPK gak ada, tapi kelihatanya ya enggak lah, sebenarnya program-programnya kita udah jalan sebelum ada perpres itu..." (IU.7)

Diketahui tiga dari tujuh informan yang mengetahui dan sudah bekerjasama lintas program terkait Perda KIA. Perda KIA juga hanya fokus pada masalah cakupan pelayanan kesehatan dan program terkait di sektor tertentu yang berhubungan dengan pelayanan kesehatan dan fokus ke intervensi spesifik. Sehingga perda KIA belum mencakup intervensi sensitif atau mencakup seluruh isi perpres 42/2013. Secara konten informan triangulasi mengatakan kalau upaya penyelamatan 1000 HPK dan penurunan stunting pernah dibahas dalam kajian RAD pada bagian ekonomi Bappeda, tetapi kajian itu berhenti dan belum ada tindak lanjut lagi.

....Sepengetahuan saya belum ada pembicaraan terkait 1000 HPK dan stunting, memang itu apa ya.. (IU2)

...Belum ada sosialisasi atau undangan terkait itu (1000 HPK dan stunting)... (IU3)

...Dulu kita sudah sempat membuat kajian RAD untuk 1000 HPK dan stunting setelah perpres itu, tapi akhirnya mandek, sampai sekarang belum jalan lagi.... (IT1)

\section{Context}

Secara konteks politik upaya penyelamatan 1000 HPK dan stunting di Kota Semarang masih harus dikoordinasikan dan difokuskan lintas sektor. Hasil penelitian menemukan bahwa semua informan dimasing-masing sektor, mengaku sudah mendapatkan dukungan yang baik dari pemerintah daerah dan pusat, tetapi hanya untuk menjalankan tugas pokok dan fungsinya masing-masing. Selama ini semua informan mengaku secara politik, permasalahan 1000 HPK dan penurunan stunting belum ada dan terkoordinasi dengan baik. Hal itu dikuatkan dengan pernyataan informan triangulasi yang mengakui Kota Semarang pernah sampai dalam tahapan kajian RAD tapi berhenti dan belum ada kabar untuk dibahas lagi maupun koordinasi dengan lintas sektor.

Secara politik di tingkat kota diakui informan utama bahwa stunting memang belum menjadi prioritas kebijakan karena faktor sudut pandang data yang dimiliki Pemerintah Kota sehingga belum ada 
upaya koordinasi dan evaluasi secara periodik dilintas sektor. Diakui juga oleh informan triangulasi, bahwa RAD di kota Semarang belum mendapatkan dukungan politik yang kuat karena faktor sudut pandang, kepentingan politik, koordinasi dan pemahaman akan prioritas kebijakan nasional.

“...Selama ini belum ada yang mampu ngelink-kan program-program terkait 1000 HPK dan stunting di masing-masing Dinas atau SKPD, selama ini masih jalan masingmasing..." (IT1)

Meskipun secara ekonomi, anggaran di masing-masing sektor pemerintahan semakin meningkat. Hal ini berdampak pada konteks sosial dan budaya masyarakat juga menjadi tidak terkontrol dan berjalan sesuai tujuan masing-masing.

".....Anggaran kami yang awalnya hanya 7 M di suruh buat jadi 25 atau 30 M...” (IU 1).

"....Anggaran program tiap tahun naik, tahun 2017 sekitar -+ 7 Milyar tahun 2018 naik jadi -+ 13 M.....(IU5)

“.....Tahun 2017 dari APBD mencapai 452 jutaan, tahun 2018 sekitar 647 jutaan, masih dapet juga APBN dan bantuan produk PMT dari pusat..." (IU-7)

\section{Process}

Proses formulasi kebijakan perda KIA diakui belum melibatkan semua lintas sektor sebagaimana pengakuan empat dari tujuh informan utama. Meskipun dalam naskah perda tertulis melibatkan lintas sektor. Sedangkan evaluasi perda KIA diakui semua informan beberapa lintas program sudah dilakukan. Semua informan mengaku tidak ada kendala yang berarti dalam proses perda KIA. Dalam proses perumusan kebijakan Perda KIA yang juga disinkronkan dengan naskah perda KIA, semua informan mengakui tidak ada pembahasan 1000 HPK dan stunting. Hal ini dikuatkan oleh informan triangulasi bahwa untuk upaya 1000 HPK dan stunting Pemerintah Kota Semarang pernah mengkaji dalam bentuk RAD (rencana aksi daerah) tapi berhenti.

“....Kalau terkait perpres dan 1000 HPK itu kita pernah mbahas, saat itu ada delapan daerah termasuk kota Semarang di Jateng, Prosesnya itu baru tahapan kajian RAD tapi akhirnya Kota Semarang mandek sampai sekarang,... (IT1)

Kendala yang ditemukan saat proses RAD ditemukan bahwa adanya variasi perbedaan pemahaman, sudut pandang kebijakan dan data stunting yang digunakan, serta prioritas yang diputuskan untuk menjadi sebuah kebijakan menjadi kendala dalam proses upaya penyelamatan 1000 HPK dan penurunan stunting di Kota Semarang.

Tahapan perda KIA kota semarang menurut informan utama dan sejalan dengan informan triangulasi tidak ada hubunganya dengan perpres $42 / 2013$, atau 1000 HPK dan stunting secara langsung. Hal itu karena anggapan dan keyakinan bahwa data stunting yang dimiliki kecil atau dikategorikan bebas masalah gizi. Meskipun secara isi materi perda KIA bisa menjadi salah satu pendukung upaya 1000 HPK dan stunting terutama pada intervensi spesifik. Dalam proses kebijakan perda KIA tidak ditemukan adanya evaluasi untuk upaya penyelamatan 1000 HPK dan stunting terhadap upaya intervensi sensitif lintas sektor. Berhentinya proses kajian RAD untuk 1000 HPK dan stunting sebagai respon perpres 42/2013 maupun 
RAN, menjadi hal yang sejalan dan berhubungan dengan meningkatnya kasus stunting di Kota Semarang berdasarkan data PSG.

\section{Pembahasan}

Terkait kajian intervensi sensitif maupun spesifik sebagaimana hasil penelitian Hasanah yang menyebutkan bahwa aspek kesadaran perilaku seperti pola konsumsi dalam frekuensi makanan, jenis keberagaman makanan, menjadi penyebab Ibu hamil mengalami Kekurangan Energi Kronis (KEK). ${ }^{15}$ Hal tersebut dikarenakan berhubungan dengan upaya intervensi sensitif seperti kebijakan pendidikan, ketersedian pangan, infrasrtuktur, sanitasi, akses pangan, pelatihan, dan pengetahuan bisa didukung dengan komitmen kebijakan RAD dan regulasi. ${ }^{8}$

Demikian juga faktor sosial budaya masyarakat yang dapat mempengaruhi perilaku dalam mengkonsumsi dan mengolah bahan pangan. Masalah tersebut jika diuraikan penyebabnya akan sangat kompleks dan memerlukan keterlibatan lintas sektor. ${ }^{2-4}$ Oleh sebab itu upaya pendekatan politik dianggap strategis dan memiliki arti penting yang menjadi akar masalah kesehatan dalam penyelamatan 1000 HPK dan penurunan stunting sebagaimana arahan perpres 42/2013 dan rencana aksi nasinal pangan dan gizi. ${ }^{16}$

Penelitian di Ghana menyimpulkan bahwa masalah gizi disebabkan oleh berbagai faktor sensitif seperti masalah karakteristik wilayah dan kesenjangan ekonomi. ${ }^{17}$ Disisi lainya hasil studi etnografi sosial budaya menjadi salah satu faktor yang ikut mempengaruhi gizi masyarakat diantaranya faktor pola konsumsi dan mengolah makanan. ${ }^{18}$ Sebuah studi negara berkembang dan miskin menyatakan tidak ada hubungan antara masalah gizi kurang pada usia dini dengan pertumbuhan ekonomi disuatu wilayah. Hal ini bisa dijadikan acuan bahwa meningkatnya ekonomi disuatu daerah bukan jaminan masyarakat bisa terbebas dari masalah gizi stunting. ${ }^{19}$

Temuan penelitian yang menemukan bahwa belum selesainya kajian RAD di Kota Semarang yang ditujukan untuk 1000 HPK dan penurunan stunting, berdampak kepada meningatnya kasus stunting di Kota Semarang berdasarkan hasil PSG 2017. Peran Pemerintah dalam hal ini Bappeda sebagai penanggung jawab suatu wilayah, dan koordinator disemua lintas sektor dalam upaya penyelamatan 1000 HPK dan penurunan stunting menjadi kunci dasar penggerak kebijakan didaerah terhadap masalah gizi yang sudah ditetapkan menjadi prioritas nasional untuk menguatkan intervensi sensitif selain intervensi spesifik. $^{2-6}$

\section{KESIMPULAN}

Secara konten perda KIA Kota Semarang fokus pada angka kematian ibu (AKI), dimana masalah gizi yang menjadi salah satu faktor AKI belum fokus pada upaya 1000 HPK dan stunting. Konten Perda KIA lebih fokus dan dominan mengatur upaya intervensi spesifik terkait pelayanan kesehatan. Sedangkan sektor non kesehatan terkait intervensi sensitif belum banyak terlihat dan diatur didalamnya. Justru secara konten upaya penyelamatan 1000 HPK dan stunting ditemukan pernah dibahas dalam kajian RAD.

Secara konteks politik, ekonomi dan sosial budaya perda KIA belum fokus, 
tidak berhubungan langsung, dan belum melibatkan semua intervensi untuk tujuan penyelamatan 1000 HPK dan stunting. Tetapi konteks politik, ekonomi dan sosial budaya 1000 HPK dan stunting pernah masuk dalam kajian RAD dan berhenti.

Secara proses perda KIA tidak melibatkan semua lintas sektor, tidak memasukan dan mengevaluasi intervensi sensitif dan spesifik non kesehatan yang bermuara pada 1000 HPK dan stunting. Kebijakan 1000 HPK dan penurunan stunting diarahkan pada kajian RAD pangan dan gizi yang sempat dikaji oleh bagian ekonomi Bappeda Kota Semarang tetapi karena masalah koordinasi, komunikasi, kepentingan politik, sudut pandang masalah dan kebijakan, prosesnya menjadi berhenti.

\section{UCAPAN TERIMAKASIH}

Penulis mengucapkan terima kasih kepada MIKM FKM UNDIP dan Pemerintah Kota Semarang atas diijinkannya melakukan penelitian ini.

\section{DAFTAR PUSTAKA}

1. ASEAN, UNICEF and WHO. Regional Report On Nutrition Security In Asean Volume 2. Bangkok. UNICEF. 2016. https://www.unicef.org/eapro/Regional _Report_on_Nutrition_Security_in_AS EAN_(Volume_2).pdf diakses 20 Agustus 2017.

2. Tim Nasional Percepatan Penanggulangan Kemiskinan. 100 Kabupaten/Kota Prioritas Untuk Intervensi Anak Kerdil (Stunting). Jakarta Pusat. Sekretariat Wakil Presiden Indonesia. 2017.

3. Kementerian Kesejahteraan Rakyat RI, \& Badan Perencanaan Pembangunan
Nasional. Kerangka Kebijakan Gerakan 1000 Hari Pertama Kehidupan. Kemenkokesra: Jakarta; 2013.

4. Kemenkokesra, dan Tim. Pedoman Perencanaan Program Gerakan Nasional Percepatan Perbaikan Gizi dalam rangka Gerakan Seribu Hari Pertama Kehidupan (1000 HPK). KemenkoKesra; Jakarta. 2013 online https://www.bappenas.go.id/files/5013 /8848/0466/PEDOMAN_SUN_10_Se pt_2013.pdf

5. Millennium Challenge Account Indonesia. Riset Formatif Stunting. MCA Indonesia. http://www.mcaindonesia.go.id/assets/uploads/media/p df/MCAIndonesia-Riset-FormatifFlyer-ID-dan-EN.pdf diakses 19 Agustus 2017.

6. Kementerian Kesehatan. Buku Saku Hasil Pemantauan Status Gizi 2017. Jakarta. Kementerian Kesehatan. 2017.

7. Kementerian Kesehatan. Buku Saku Hasil Pemantauan Status Gizi 2016. Jakarta. Kementerian Kesehatan. 2016.

8. Buse K, Mays N \& Will G. Making Health Policy: Understanding Public Health. Chapter 1;5. Open University Press McGraw - Hill House. Berkshire England. UK. 2005.

9. Peraturan Presiden nomor 42 tahun 2013 tentang Gerakan Nasional Percepatan Perbaikan Gizi. Jakarta. 2013.

10. Peraturan Daerah Kota Semarang nomor 2 tahun 2015 tentang Keselamatan Ibu dan Anak. Semarang. 2015.

11. Sugiyono. Metode Penelitian Kuantitatif, Kualitatif dan $R$ \& $D$. Alfabeta; Bandung. 2008.

12. Notoatmojo S. Metodologi Penelitian 
Kesehatan. Vol Pertama. Jakarta: Rineka Cipta; 2010.

13. Murti, Bhisma. Desain dan Ukuran Sampel Untuk Penelitian Kuantitatif dan Kualitatif di Bidang Kesehatan. Edisi ke-2. Gajah Mada University Press; Yogyakarta. 2010.

14. Ayuningtyas, D. Kebijakan Kesehatan, Prinsip dan Praktik. Rajawali Pers; Jakarta. 2014.

15. Hasanah, N D, dkk. Kebiasaan Makan Menjadi Salah Satu Penyebab Kekurangan Energi Kronis (KEK) Pada Ibu Hamil Di Poli Kebidanan RSI \& A Lestari Cirendeu Tangerang Selatan. Jurnal Kesehatan Reproduksi Vol. 3 No 3, Desember 2012 : 91-104.

16. Pallutturi, S. Pentingnya Politik Bidang Kesehatan. Jurnal AKK, Vol 2 No 3, September 2013, hal 42-46.

17. Konings, P., Harper, S., Lynch, J., Hosseinpoor, A. R., Berkvens, D., Lorant, V., Speybroeck, N. Analysis of socioeconomic health inequalities using the concentration index. International Journal of Public Health, 55 (1), 2010: 71-74.

18. Laksono, AD. Anyiman, Studi Etnografi Makanan Suku Muyu. Yogyakarta. PT Kanisius. 2015.

19. Vollmer S, Harttgen K, Subramanyam MA, Finlay J, Klasen S, Subramanian SV. Association between economic growth and early childhood undernutrition: evidence from 121 Demographic and Health Surveys from 36 low-income and middleincome countries. Lancet Global Health. 2014;2:e225-34 